\title{
APLIKASI PEMBAYARAN DSP DAN SPP SEKOLAH PADA SMK TI BINTRA PURWOKERTO
}

\author{
1) Joko Dwi Mulyanto, ${ }^{2)}$ Uswatun Khasanah \\ 1) Sistem Informasi, STMIK Nusa Mandiri Jakarta \\ joko.jdm@nusamandiri.ac.id \\ 2) Manajemen Informatika, AMIK BSI Purwokerto \\ uswatunk1504@bsi.ac.id
}

\begin{abstract}
The payment system of DSP and SPP at Vocational High School of Information Technique of Bina Citra Informatika Purwokerto still done manually. In the processing of payment data is still conventional with data collection system that is now felt there are still many shortcomings that occur, because the existing system still uses sheets of paper so it can cause the data is easily lost or damaged. System development in the form of DSP payment application And SPP school in Vocational High School of Information Engineering Bina Citra Informatika Purwokerto is a computerized system that provides convenience in data processing payments, so as to manage and process data effectively and efficiently. In addition to the computerized system then the resulting information is much more accurate. In this system, the application can only be accessed by users ie employees and administrators. In this study in addition to explaining the study of theories used as the basis of preparation, will also be discussed about the design of applications and making payment applications. So it is expected to be implemented in a product that will fix any shortcomings that exist in the old system. The method used in the development of this system is SDLC (System Development Life Cycle) with waterfall process model.
\end{abstract}

\section{Keywords: Payment Application, DSP and SPP, Computerized system.}

\begin{abstract}
Abstrak - Sistem pembayaran DSP dan SPP sekolah pada Sekolah Menengah Kejuruan Teknik Informasi Bina Citra Informatika Purwokerto masih dilakukan secara manual. Dalam pengolahan data pembayaran masih secara konvensional dengan sistem pendataan yang sekarang dirasakan masih banyak kekurangan yang terjadi, dikarenakan sistem yang ada masih menggunakan lembaran kertas sehingga dapat menyebabkan data-data yang ada mudah hilang ataupun rusak. Pengembangan sistem berupa aplikasi pembayaran DSP Dan SPP sekolah pada Sekolah Menengah Kejuruan Teknik Informasi Bina Citra Informatika Purwokerto merupakan sistem terkomputerisasi yang memberikan kemudahan dalam pengolahan data pembayaran, sehingga dapat mengelola dan memproses data secara efektif dan efisien. Selain itu dengan sistem terkomputerisasi maka informasi yang dihasilkan jauh lebih akurat. Pada sistem ini, aplikasi hanya dapat diakses oleh user yaitu pegawai dan administrator. Dalam penelitian ini selain memaparkan kajian teori yang digunakan sebagai dasar penyusunan, juga akan dibahas mengenai perancangan aplikasi dan pembuatan aplikasi pembayaran. Sehingga diharapkan dapat diimplementasikan dalam sebuah produk yang akan memperbaiki segala kekurangan yang ada pada sistem lama. Metode yang digunakan dalam pengembangan sistem ini yaitu SDLC (System Development Life Cycle) dengan model proses waterfall.
\end{abstract}

\section{Kata Kunci: Aplikasi Pembayaran, DSP dan SPP, Sistem terkomputerisasi.}

\section{A. PENDAHULUAN}

Pada saat ini perkembangan teknologi informasi berkembang dengan sangat pesat. Secara langsung atau tidak langsung berpengaruh terhadap berbagai aspek kehidupan, termasuk didalamnya dunia pendidikan. Teknologi yang biasa digunakan untuk membangun sistem informasi adalah aplikasi teknologi informasi berbasis komputer. Komputer berasal dari bahasa Yunani, yaitu computare yang secara bahasa berarti menghitung. Berdasarkan hal tersebut, maka komputer secara bahasa adalah sebuah alat yang melakukan proses perhitungan aritmatika. Sedangkan secara harfiah, komputer adalah sebuah alat elektronika yang memiliki kemampuan untuk melakukan pengolahan data informasi yang berupa teks, gambar maupun suara untuk menghasilkan output/keluaran yang di kehendaki.

Dengan adanya komputer maka akan memicu pula sistem terkomputerisasi. Sistem merupakan serangkaian aktifitas yang dilakukan untuk mencapai suatu tujuan tertentu. Sedangkan sistem terkomputerisasi merupakan sebuah sistem yang melibatkan teknologi dalam pencapaian tujuan sehingga 
sebuah aktifitas dapat dilaksanakan dengan efektif. Selain untuk keefektifan dan keefisienan waktu dalam mengelola dan memproses data, informasi yang dihasilkan jauh lebih akurat.

Namun masih banyak instansi yang belum menggunakan sistem terkomputerisasi dalam menjalankan aktifitasnya. Salah satu instansi yang masih menggunakan cara manual dalam pengolahan data khususnya dibagian pembayaran DSP dan SPP sekolah adalah SMK Teknik Informasi Bina Citra Informatika Purwokerto, sekolah ini terletak di desa Sumampir kecamatan Purwokerto Utara. Dengan menggunakan sistem terkomputerisasi diharapkan dapat mempercepat pengolahan dan penyimpanan data yang lebih baik serta mengurangi kesalahan pencatatan akibat human error. Oleh karenanya perlu dibuat sebuah sistem terkomputerisasi yang dapat meningkatkan kinerja dan menghemat waktu serta biaya.

\section{B. TINJAUAN PUSTAKA}

1. Konsep Dasar Program

a) Program

Menurut Junaedi (2007:3) "Program adalah serangkaian kode yang dituliskan dalam bahasa pemrograman tertentu, seperti bahasa C, $\mathrm{C}_{++}$, Pascal, FORTRAN, JAVA, CGI, Perl, Cobol, ASP (Active Server Pages), PHP dan sebagainya, yang umumnya merupakan penjabaran algoritma yang telah dibuat".

Menurut Kadir (2012:2) "Program adalah kumpulan instruksi yang digunakan untuk mengatur komputer agar melakukan suatu tindakan tertentu". Itulah sebabnya sering dikatakan bahwa komputer mencakup tiga aspek penting, berupa perangkat keras (hardware), perangkat lunak (software) yang dalam hal ini berupa program, dan perangkat akal (brainware) atau orang yang berperan terhadap operasi komputer maupun pengembangan perangkat lunak.

b) Bahasa Pemograman
Menurut
Kadir
(2012:2)
"mengemukakan bahwa Bahasa pemrograman dapat dianalogikan dengan bahasa yang digunakan manusia (bahasa manusia)". Kumpulan instruksi dalam bahasa manusia yang berupa sejumlah kalimat dapat anda analogikan dengan suatu program. Manusia dapat mengerjakan suatu instruksi berdasarkan kalimat-kalimat dan komputer bisa menjalankan suatu

instruksi menurut program. Dalam konteks pemrograman, terdapat sejumlah bahasa pemrograman seperti Pascal, C, dan BASIC. Secara garis besar, bahasa-bahasa pemrograman dapat dikelompokkan menjadi:

1) bahasa beraras-tinggi (high-level language)

Bahasa beraras-tinggi adalah bahasa pemrograman yang berorientasi kepada bahasa manusia. Program dibuat menggunakan bahasa pemrograman yang mudah dipahami manusia. Biasanya menggunakan kata-kata bahasa inggris; misalnya IF untuk menyatakan "jika" dan AND untuk menyatakan "dan". Termasuk dalam kelompok bahasa ini yaitu Java, $\mathrm{C}++$, Pascal, dan BASIC.

2) bahasa beraras-rendah (low-levellanguage)

Bahasa beraras-rendah adalah bahasa pemrograman yang berorientasi kepada mesin. Bahasa ini menggunakan kode biner (yang hanya mengenal kode 0 dan 1 ), atau suatu kode sederhana untuk menggantikan kode-kode tertentu dalam sistem biner. Yang tergolong dalam kelompok bahasa ini adalah bahasa mesin dan bahasa rakitan. Bahasa-bahasa tersebut sangat sulit dipahami orang awam dan sangat membosankan bagi pemrogram. Pemrogram harus benar-benar menguasai operasi komputer secara teknis. Namun, bahasa generasi ini memberikan eksekusi program yang sangat cepat. Selain itu, bahasa mesin bersifat sangat bergantung pada mesin (machine dependent); Artinya, bahasa mesin antara satu mesin dengan mesin yang lain jauh berbeda.

c) Basis Data

Menurut Fathansyah (2007:2) Basis data terdiri atas 2 kata, yaitu Basis dan Data. Basis kurang lebih dapat diartikan sebagai markas atau gudang, tempat bersarang/berkumpul. Sedangkan data adalah representasi fakta dunia nyata yang mewakili suatu objek seperti manusia (pegawai, siswa, pembeli, pelanggan), barang, hewan, peristiwa, konsep, keadaan, dan sebagainya, yang direkam dalam bentuk angka, huruf, simbol, teks, gambar, bunyi, atau kombinasinya. Contoh basis data: 
1) MySQL

Menurut Nugroho (2009:91)

"MySQL (My Structured Query

Languange) atau yang biasa dibaca mal-se-kuel adalah sebuah program pembuat dan pengelola database atau yang sering disebut dengan DBMS (Database Management System), sifat dari DBMS ini adalah Open Source". MySQL merupakan program pengakses database yang bersifat jaringan, sehingga dapat digunakan untuk aplikasi Multi User (banyak pengguna). Kelebihan lain dari MySQL adalah menggunakan bahasa query (permintaan) standar SQL (Structured Query Languange), SQL adalah suatu bahasa permintaan yang terstruktur.

Program-program aplikasi yang mendukung MySQL adalah PHP (Page Hipertext Preprosesor), Borland Delphi, Borland $\mathrm{C}++$ Builder, Visual Basic 5.0/6.0 dan .Net, Visual FoxPro, Cold Fusion

2) phpMyAdmin

Menurut Nugroho (2008:88) "phpMyAdmin adalah suatu aplikasi Open Source yang berbasis web, aplikasi ini dibuat menggunakan program PHP, fungsi dari aplikasi ini adalah untuk mengakses database MySQL". Dengan adanya aplikasi ini akan sangat mempermudah dan mempersingkat kinerja dalam mengelola database MySQL. Dengan adanya kelebihan yang dimilikinya mengakibatkan para pengguna awam tidak harus mampu untuk mengetahui perintah-perintah MySQL dalam pembuatan Database dan Tabel.

d) Model Pengembangan Perangkat Lunak

Model pengembangan perangkat lunak merupakan sebuah metode untuk mengembngkan dan mengimplementaikan perangkat lunak menggunakan suatu metodologi pengembangan perangkat lunak.

Menurut Rosa dan Shalahudin (2014:26) SDLC atau Software Development Life Cycle atau sering disebut juga System Development Life Cycle adalah proses mengembangkan atau mengubah suatu sistem perangkat lunak dengan menggunakan modelmodel dan metodologi yang digunakan orang untuk mengembangkan sistemsistem perangkat lunak sebelumnya (berdasarkan best pratice atau caracara yang sudah teruji baik).

Metodologi yang digunakan dalam aplikasi pembayaran DSP dan SPP sekolah ini adalah waterfall. Berikut gambar air terjun dalam Rosa dan Shalahudin (2014:29)

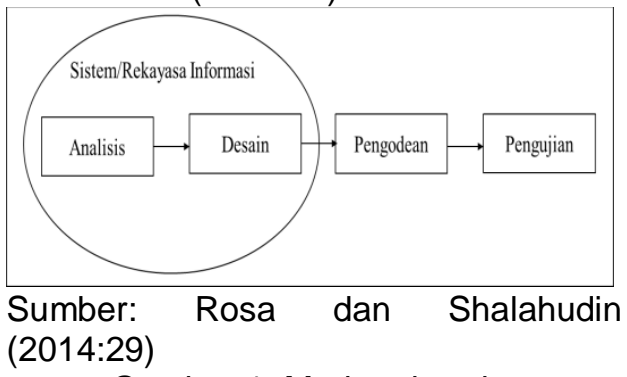

Gambar 1. Moder air terjun

e) Aplikasi Perangkat Lunak

1) Visual Basic 6.0

Pengertian microsoft visual basic 6.0 menurut MADCOMS (2010:2) merupakan bahasa pemrograman yang cukup populer dan mudah untuk dipelajari. Anda dapat membuat program dengan aplikasi GUI (Graphical User Interface) atau program yang memungkinkan pemakai komputer berkomunikasi dengan komputer tersebut dengan menggunakan modus grafik atau gambar. Tampilan awal dari jendela program microsoft visual basic 6.0 seperti pada gambar 2

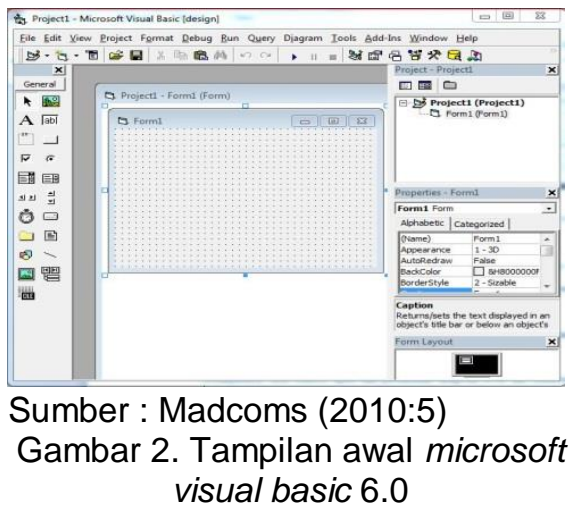

(a) Title bar yang berfungsi untuk menampilkan judul atau nama jendela.

(b) Toolbar merupakan sebuah batang yang berisi kumpulan tombol yang terletak dibagian bawah Menu bar, yang dapat digunakan untuk menjalankan suatu perintah. Pada kondisi default, program Visual Basic hanya menampilkan toolbar Standard. 
(c) Toolbox

Toolbox merupakan kotak perangkat yang berisi kumpulan tombol objek atau kontrol untuk mengatur desain dari aplikasi yang akan dibuat. Pada kondisi default, toolbox menampilkan tabulasi general dengan 21 tombol kontrol.

(d) Project

Project merupakan suatu kumpulan module atau merupakan program aplikasi itu sendiri. Dalam Visual Basic, file project disimpan dengan nama file berakhiran .VBP, dimana file ini berfungsi untuk menyimpan seluruh komponen program.

Apabila anda membuat suatu program aplikasi baru, maka secara otomatis project tersebut akan diisi dengan objek form1. Dalam jendela Project Explorer, ditampilkan suatu sruktur hirarki dari sebuah project itu sendiri yang berisi semua item yang terkandung didalamnya.

(e) Jendela Properties

Jendela properties merupakan sebuah jendela yang digunakan untuk menampung nama properti suatu kontrol. Pengaturan properti pada program Visual Basic merupakan hal yang sangat penting untuk membedakan objek yang satu dengan yang lainnya. Pada jendela properti ditampilkan jenis dan nama objek yang anda pilih urut berdasarkan abjad pada tab Alphabetic atau berdasarkan kategori pada tab Categorized.

(f) Jendela Form Layout Jendela form layout merupakan sebuah jendela yang digunakan untuk mengatur posisi dari form pada saat program dijalankan. Pada saat anda mengarahkan pointer mouse ke bagian form, maka pointer mouse akan berubah menjadi anak panah empat arah.

(g) Jendela Immediate

Jendela immediate merupakan sebuah jendela yang digunakan untuk mencoba beberapa perintah dengan mengetikkan baris program dan anda dapat secara langsung melihat hasilnya. Hal tersebut biasa dilakukan dan sangat membantu proses pengujian suatu perintah sebelum dipasang dalam program.

(h) Jendela Form

Jendela form merupakan jendela desain dari sebuah program aplikasi. Anda dapat mendesain sebuah program aplikasi dengan menempatkan kontrol-kontrol yang ada di bagian Toolbox pada area form.

(i) Close Window

Close window merupakan sebuah jendela yang digunakan untuk menuliskan kode program dari kontrol yang anda pasang pada jendela form dengan cara memilih terlebih dahulu kontrol tersebut pada kotak objek.

(j) Event

Event merupakan suatu kejadian yang akan diterima oleh suatu objek.

Event yang diterima oleh objek berfungsi untuk menjalankan kode program yang ada di dalam objek tersebut.

Private Sub Command1_Click

Baris kode diatas menunjukkan penggunaan event Click pada objek Command1, yang mempunyai arti apabila objek Command1 diklik maka kode program yang terletak di bawah baris kode program tersebut akan dijalankan.

(k) Method

Method merupakan suatu kumpulan perintah yang memiliki kegunaan yang hampir sama dengan suatu fungsi atau prosedur, tetapi perintah-perintah tersebut sudah disediakan dalam suatu objek.

Suatu method dapat dipanggil dengan cara menyebutkan nama objek dan diikuti dengan tanda titik dan nama metodenya. Method umumnya digunakan untuk menjalankan perintah khusus pada suatu objek tertentu.

(I) Module

Module hampir sama fungsinya dengan form, tetapi module tidak berisi

objek dan bentuk standar, dan module berisi kode program atau 
prosedur yang dapat digunakan 2) XAMPP oleh program aplikasi.

\section{Menurut Wardana (2016:4) "Xampp adalah paket software yang didalamnya sudah terkandung Web Server Apache, database MySql, dan PHP Interpreter". Berikut ini tampilan Control Panel Xampp.}

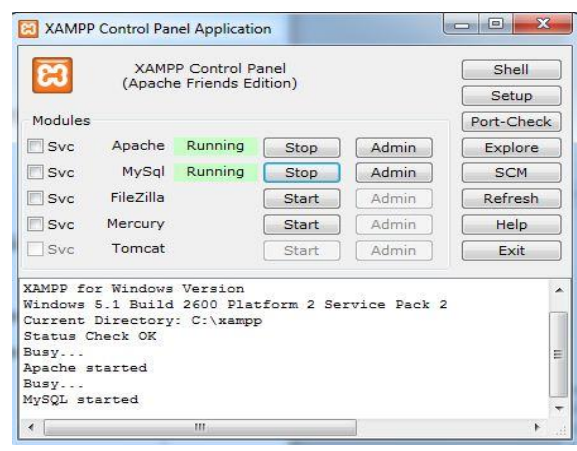

Sumber: Wardana (2016:5)

Gambar 3. Tampilan Control Panel Xampp

Keterangan:

(a) Apache, web server

(b) MySQL, database mysql

(c) Filezilla, untuk transfer antarkomputer

(d) Mercury, berhubungan dengan fitur email

3) Crystal Report

Menurut MADCOMS (2010:234)

"Cyrstal Report merupakan program yang terpisah dengan program Microsoft Visual Basic 6.0, tetapi keduanya dapat dihubungkan(Linkage)". Membuat laporan dengan Cyrstal Report hasilnya lebih baik dan lebih mudah, karena pada Crystal Report banyak tersedia objek-objek maupun komponen yang mudah digunakan.

\section{f) Pembayaran}

Menurut Kartono (2009:64) "Sistem pembayaran merupakan wujud nilainilai (values) yang diperjuangan dan dihidupi sebuah lembaga pendidikan". Dalam aplikasi yang penulis buat ada dua pembayaran yaitu pembayaran dana sumbangan sekolah (DSP) dan pembayaran sumbangan pembinaan pendidikan (SPP).

\section{Tools Program}

Perancangan sebuah aplikasi tidak terlepas dari penggunaan peralatan pendukung (Tools Program), Penggunaan peralatan pendukung dalam perancangan aplikasi bisa menambah kemudahan dalam merencanakan prosedur-prosedur yang akan dipakai pada aplikasi tersebut. Pada perancangan kali ini penulis menggunakan beberapa peralatan pendukung diantaranya:

a) Entity Relationship Diagram (ERD) Menurut Simarmata dan Paryudi (2010:59) mengemukakan bahwa:

Entity relationship (ER) data model didasarkan pada persepsi terhadap dunia nyata yang tersusun atas kumpulan objek-objek dasar yang disebut entitas dan hubungan antarobjek. Entitas adalah sesuatu atau objek dalam dunia nyata yang dapat dibedakan dari objek lain. Sebagai contoh, masing-masing mahasiswa adalah entitas dan mata kuliah dapat pula dianggap sebagai entitas.

Struktur logis (skema database) dapat ditunjukan secara grafis dengan diagram ER yang dibentuk dari komponen-komponen berikut:

Tabel 1. Komponen ER

\begin{tabular}{|c|c|}
\hline Simbol & Keterangan \\
\hline Entitas & $\begin{array}{l}\text { Persegi panjang } \\
\text { mewakili kumpulan } \\
\text { entitas }\end{array}$ \\
\hline & $\begin{array}{ll}\text { Elips } & \text { mewakili } \\
\text { atribut } & \end{array}$ \\
\hline & $\begin{array}{l}\text { Belah ketupat } \\
\text { mewakili relasi }\end{array}$ \\
\hline & $\begin{array}{l}\text { Garis } \\
\text { menghubungkan } \\
\text { atribut dengan } \\
\text { kumpulan entitas } \\
\text { dan kumpulan } \\
\text { entitas dengan } \\
\text { relasi } \\
\end{array}$ \\
\hline
\end{tabular}

Sumber : Simarmata dan Paryudi (2010:60)

Model ER menyajikan pula batasan dimana isi basisdata harus menyesuaikan dengan batasan. Salah satu batasan yang penting adalah pemetaan kardinallitas (mapping cardinalities), yang menggambarkan jumlah entitas yang berhubungan dengan entitas lain melalui suatu relasi. Menurut Lubis (2016:42) Dalam ER-D hubungan antara entitas dapat dipetakan menjadi beberapa pembatas, yaitu:

1) Satu-ke-satu atau one-to-one (1-1) 
Pembacaan pemetaan satu-ke-satu dalam ER-D, berarti bahwa setiap entitas akan berhubungan dengan palig banyak satu entitas yang lain, demikian sebaliknya. Misalnya entitas $A$ akan berhubungan dengan maksimal satu entitas $B$. Ini berarti satu entitas $A$ maksimum hanya berhubungan satu pda entitas $B$.

2) Satu-ke-banyak atau one-to-many $(1-M / N)$

Pembacaan pemetaan satu-kebanyak adalah satu atribut dapat berhubungan dengan lebih dari satu(banyak) atribut yang lain, tetapi tidak sebaliknya lebih dari satu entitas B. Ini berarti satu entitas A dapat berhubungan dengan lebih dari satu entitas $B$, sedangkan banyak atribut $B$ hanya berhubungan dengan satu atribut $A$.

3) Banyak-ke-satu atau many-to-one $(\mathrm{M} / \mathrm{N}-1)$

Hubungan banyak-ke-satu merupakan kebalikan dari hubungan satu ke banyak, yaitu banyak (lebih dari satu) entitas yang satu akan berhubungan dengan hanya satu pada entitas yang lain, namun tidak sebaliknya. Misalnya entitas A berhubungan dengan hanya satu pada entitas $B$, sedangkan entitas $B$ hanya dapat berhubungan dengan satu pada entitas $A$.

4) Banyak-ke-banyak atau many-tomany $(\mathrm{M}-\mathrm{N})$

Pembacaan pemetaan banyak-kebanyak, ini berarti banyak entitas dapat dihubungkan dengan banyak entitas yang lain, demikian sebaliknya. Misalnya banyak entitas A berhubungan dengan banyak entitas B dan berlaku sebaliknya, entitas $B$ berhubungan dengan banyak entitas $A$.

b) Logical Record Structure (LRS)

Menurut Tabrani (2014:35) mengemukakan bahwa Logical Record Structure dibentuk dengan nomor dari tipe record digambarkan oleh kotak empat persegi panjang dan dengan nama yang unik. Perbedaan LRS dengan $\mathrm{E}-\mathrm{R}$ diagram adalah nama tipe record berada diluar kotak field tipe record ditempatkan.

Logical Record Structure terdiri dari link-link diantara tipe record. Link ini menunjukkan arah dari satu tipe record lainnya. Banyak link dari LRS yang diberi tanda field-field yang kelihatan pada kedua link tipe record. Penggambaran LRS mulai dengan menggunakan model yang dimengerti. Dua metode yang digunakan, dimulai dengan hubungan kedua model yang dapat dikonverensikan ke LRS, metode yang lain dimulai dengan ER-diagram dan langsung dikonversikan ke LRS.

c) Pengkodean

Digunakan untuk mengklasifikasikan data, yang dimasukkan kedalam komputer ataupun untuk mengambil bermacam-macam informasi. Kode dapat terbentuk dari kumpulan angka, huruf atau simbol lainnya.

Menurut Kusrini dan Koniyo (2007:23) "Kode akun adalah pemberian tanda/nomor tertentu dengan memakai angka, huruf, atau kombinasi angka dan huruf pada setiap akun atau rekening". Kode akun meliputi kode numerikal, desimal, mnemonik, serta kode kombinasi huruf dan angka.

1) Kode Numerikal

Kode numerikal adalah cara pengkodean akun berdasarkan nomor urut, yang dapat dimulai dari angka 1,2,3 dan seterusnya.

2) Kode Desimal

Kode desimal adalah cara pemberian kode akun dengan menggunakan lebih dari satu angka. Setiap angka mempunyai makna atau karakter sendiri. Kode desimal dapat dibedakan atas kode kelompok, kode blok, kode stelse akun desimal

3) Kode Mnemonik

Kode mnemonik adalah cara pengkodean akun dengan menggunakan huruf tertentu, misal akun harta dengan kode ' $\mathrm{H}$ ', akun hutang dengan huruf ' $U$ ', dan akun modal dengan huruf ' $M$ '.

4) Kode Akun dengan Sistem kombinasi Huruf dan Angka

Sistem kombinasi huruf dan angka adalah cara pengkodean dengan kombinasi antara huruf dan angka.

d) Hierarchy Input Process Output (HIPO) Menurut Fatta (2007:147) HIPO merupakan teknik untuk mendokumentasikan pengembangan suatu sistem yang dikembangkan oleh IBM. HIPO dapat digunakan untuk memenuhi kebutuhan beberapa pengguna untuk kepentingan berbedabeda, antara lain:
1) Seorang
manajer menggunakan
dapat HIPO 
untuk memperoleh gambaran umum sistem.

2) Seorang programer menggunakan HIPO untuk menentukan fungsifungsi dalam program yang dibuatnya.

3) Programer juga dapat menggunakan HIPO untuk mencari fungsi-fungsi yang dimodifikasi dengan cepat.

Teknik ini mempunyai beberapa tujuan utama. Pertama dapat dibuat sebuah struktur yang menggambarkan hubungan antar fungsi dalam program secara hierarkis. Sasaran kedua adalah untuk menentukan fungsi-fungsi apa saja yang harus ada dalam sistem yang dikembangkan. Sasaran ketiga adalah untuk mendapatkan gambaran input dari fungsi dan output apa yang dihasilkan.

Paket HIPO terdiri dari 3 jenis diagram, yaitu diagram daftar isi visual (visual table of content) Diagram ringkas (overview diagram, dan diagram rinci (detail diagram).

1) Daftar Isi Visual(DIV)

Diagram ini membuat semua modul yang ada dalam sistem berikut nama

dan nomornya, yang nantinya akan diperinci dalam diagram ringkas dan diagram rinci. Dalam DIV juga bisa dilihat fungsi-fungsi utama yang menyusun sebuah sistem dan hubungan antar fungsi tersebut.

2) Diagram Ringkas

Diagram ringkas menerangkan input, proses, dan output dari sistem. Diagram

ringkas menggambarkan input dan output dari fungsi-fungsi yang telah didefinisikan dalam daftar isi visual.

3) Diagram Rinci

Diagram rinci HIPO digunakan untuk memperinci input, proses, dan output yang telah digambarkan dalam diagram ringkas. Dalam input data dijelaskan field-field datanya secara detail. Untuk fungsi, juga dideskripsikan proses apa yang dilakukan oleh fungsi-fungsi tersebut. Rincian field-field data output juga dengan lebih detail.

e) Diagram Alir Data (Flowchart)

Merupakan alat yang digunakan untuk menggambarkan sebuah algoritma. Menurut Sitorus (2015:14) flowchart menggambarkan urutan logika dari suatu prosedur masalah, sehingga flowchart merupakan langkah-langkah penyelesaian masalah yang dituliskan dalam simbol-simbol tertentu. Menurut Rachmat (2010:15) "flowchart merupakan alur pemikiran yang dituangkan kedalam bentuk gambar/simbol". Dengan menggunakan flowchart (diagram alir) maka seorang programmer dapat memberikan idenya secara tertulis sehingga dapat dipahami oleh programmer lain, oleh klien, atau oleh tim kerjanya.

Ada dua bentuk flowchart diantaranya

1) Program Flowchart

Yaitu simbol-simbol flowchart yang digunakan untuk menggambarkan logik dari pemrosesan terhadap data. Dalam Suarga (2012:10) simbol yang digunakan dalam program flowchart yaitu:

Tabel 2. Simbol Program Flowchart

\begin{tabular}{|c|c|}
\hline Simbol & Keterangan \\
\hline & $\begin{array}{l}\text { Terminator, mulai } \\
\text { atau selesai. }\end{array}$ \\
\hline & $\begin{array}{l}\text { Proses, } \\
\text { menyatakan proses } \\
\text { terhadap data. }\end{array}$ \\
\hline & $\begin{array}{l}\text { Input/Output, } \\
\text { menerima input } \\
\text { atau menampilkan } \\
\text { output. }\end{array}$ \\
\hline & $\begin{array}{l}\text { Seleksi/Pilihan, } \\
\text { memilih aliran } \\
\text { berdasarkan } \\
\text { syarat. }\end{array}$ \\
\hline & $\begin{array}{l}\text { Predefined-Data, } \\
\text { definisi awal dari } \\
\text { variabel atau data. }\end{array}$ \\
\hline & $\begin{array}{l}\text { Predefined- } \\
\text { Process, lambang } \\
\text { fungsi atau sub- } \\
\text { program. }\end{array}$ \\
\hline & $\begin{array}{l}\text { Connector, } \\
\text { penghubung. }\end{array}$ \\
\hline & $\begin{array}{ll}\text { Off-page } & \\
\text { Connector, } & \\
\text { penghubung } & \\
\text { penghubung } & \text { pada } \\
\text { halaman } & \text { yang } \\
\text { berbeda } & \end{array}$ \\
\hline
\end{tabular}

Sumber : Suarga (2012:10)

2) System Flowchart 
Merupakan simbol-simbol peralatan sistem komputer yang digunakan untuk menyatakan proses pengolahan data. Dalam Suarga (2012:10) simbol yang digunakan dalam system flowchart yaitu:

Tabel 3. Simbol System Flowchart

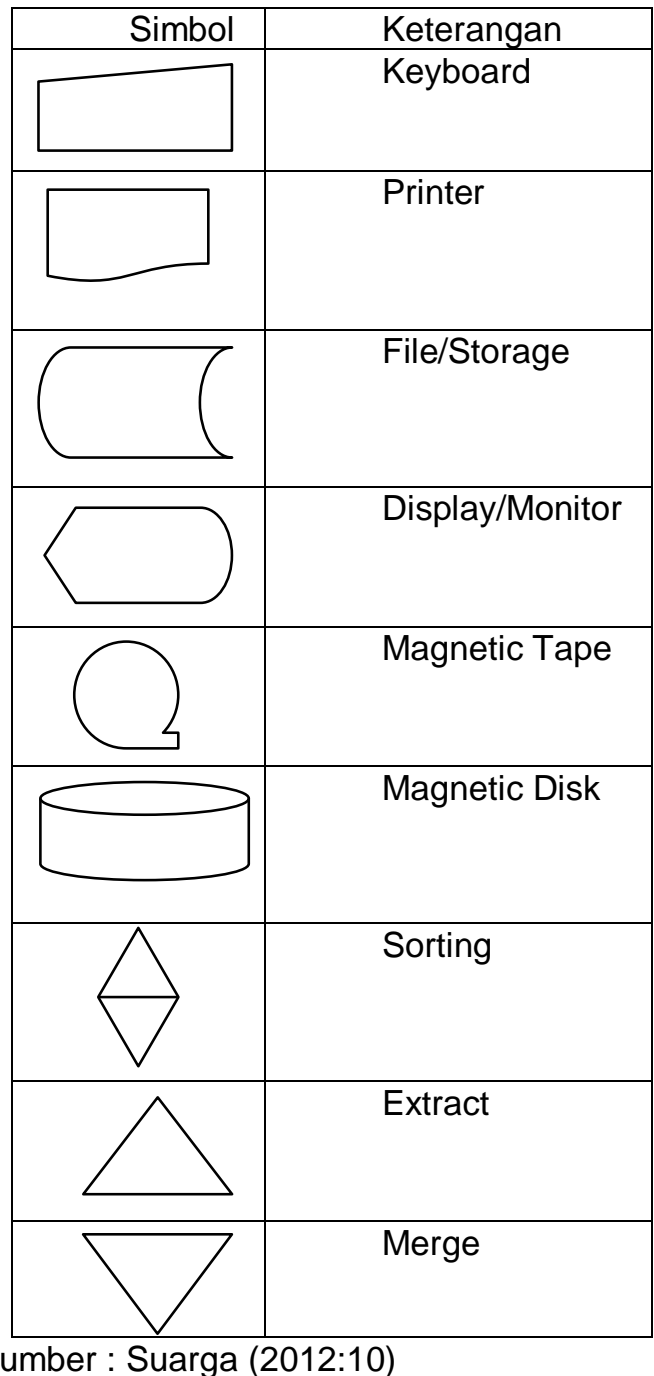

Dalam menyusun flowchart dibutuhkan teknik-teknik pembuatan flowchart, diantaranya:

1) General Way

Cara ini sering digunakan dalam penyusunan logika suatu program, yang menggunkan pengulangan proses secara tidak langsung (Non-Direct Loop).

2) Iteration Way

Cara ini sering dipakai untuk logika program yang cepat, serta bentuk permasalahan yang kompleks, pengulangan proses yang terjadi bersifat langsung (Direct Loop).

\section{METODE PENELITIAN}

Metode penelitian dalam penulisan ini diantaranya:

1. Metode Pengamatan Langsung (Observation)

Melakukan pengamatan terhadap kegiatan yang berkaitan dengan pembayaran dana sumbangan pembangunan sekolah. Observasi dibutuhkan untuk mendapatkan data-data yang diperlukan seperti data tentang SMK Teknik Informasi Bina Citra Informatika Purwokerto, data siswa, data pegawai smk, data pembayaran pembangunan sekolah, data pembayaran sumbangan pembinaan pendidikan sekolah dan lain-lain.

2. Metode Wawancara(Interview)

Wawancara dilakukan untuk mendapatkan informasi yang akurat. Wawancara dilakukan kepada pihak sekolah yaitu kepala TU mengenai sistem berjalan pembayaran dana sumbangan pembangunan sekolah dan pembayaran sumbangan pembinaan pendidikan sekolah.

3. Metode Studi Pustaka(Literature)

Selain melakukan observasi dan wawancara, studi pustaka juga diperlukan untuk membantu menganalisa prosedur pada SMK Teknik Informasi Bina Citra Informatika Purwokerto. Studi Pustaka dilakukan dengan mempelajari buku-buku yang sesuai atau relevan dengan topik penulisan ini.

\section{HASIL DAN PEMBAHASAN}

Berikut ini adalah hasil rancangan untuk aplikasi pembayaran DSP dan SPP sekolah pada SMK TI BINTRA Purwokerto. Tampilan awal aplikasi pembayaran DSP dan SPP sekolah adalah form login yang digunakan untuk login pengguna.

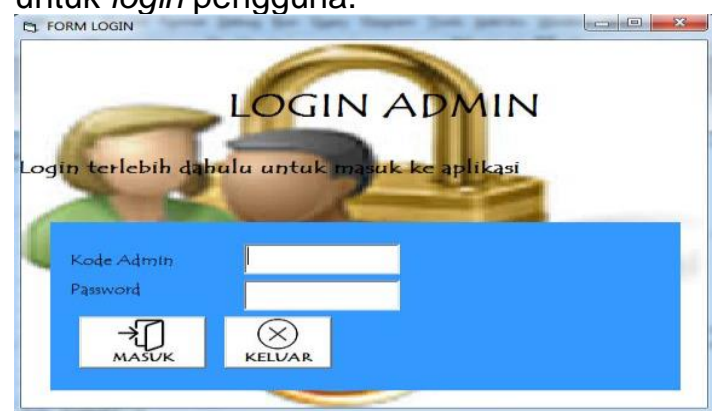

Gambar 4. Tampilan form login

Setelah memasukan kodeadmin dan paswword, halaman menu utama akan tampil dengan menu-menu tertentu yang dapat diakses oleh pengguna. 


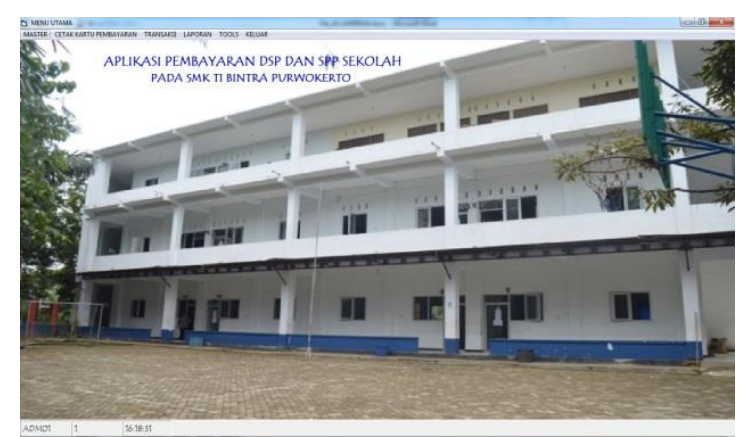

Gambar 5. Tampilan form menu utama

Tampilan pada gambar 6 , gambar 7 , gambar 8, gambar 9, gambar 10, gambar 11, dan gambar 12 merupakan tampilan untuk memasukan data siswa, data biaya DSP, data biaya SPP, data kartu pembayaran DSP, data kartu pembayaran SPP, data transaksi DSP, dan data transaksi SPP.

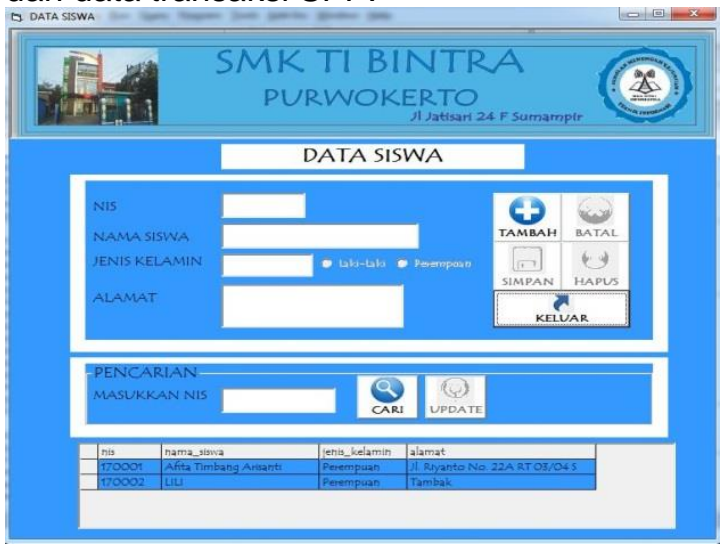

Gambar 6. Tampilan form siswa

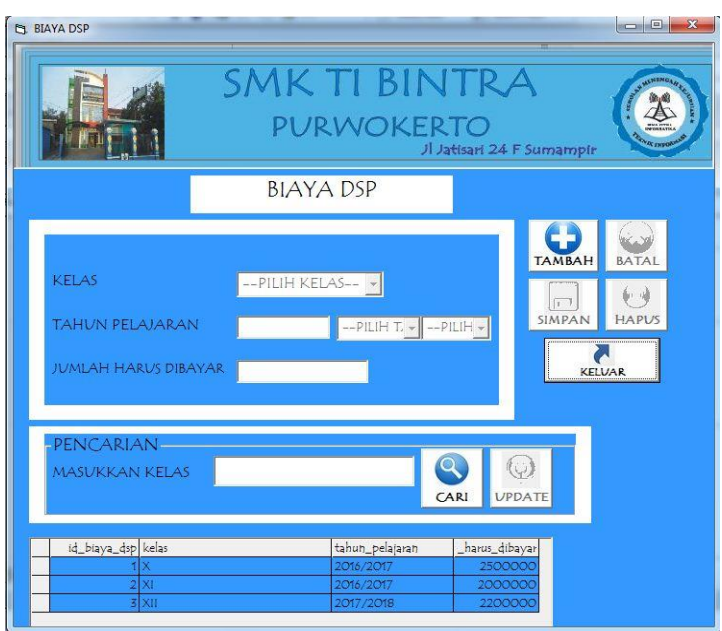

Gambar 7. Tampilan form biaya DSP

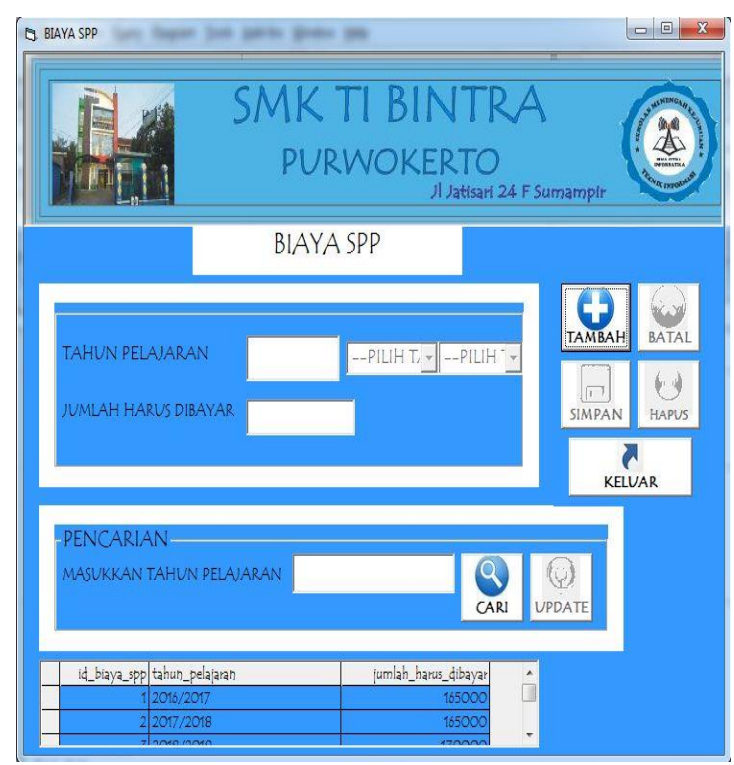

Gambar 8. Tampilan form biaya SPP

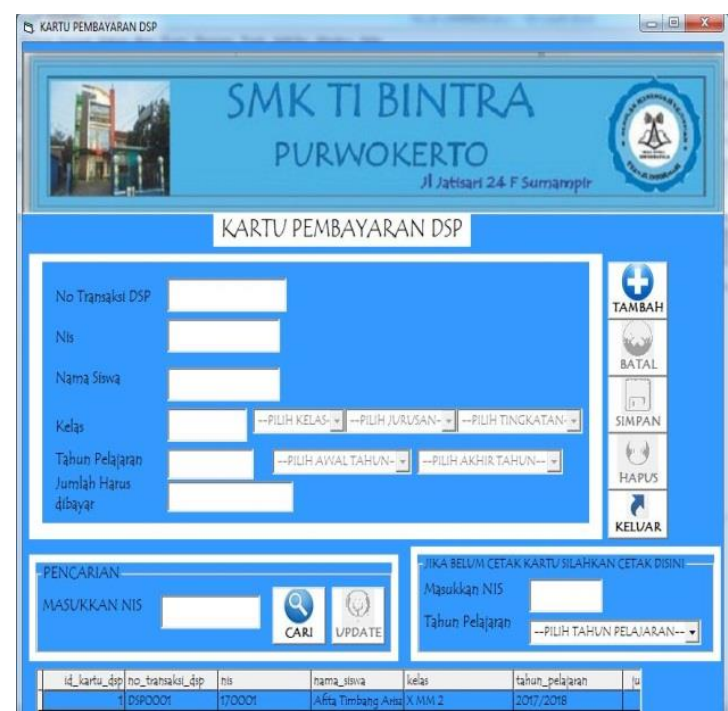

Gambar 9. Tampilan form kartu pembayaran DSP

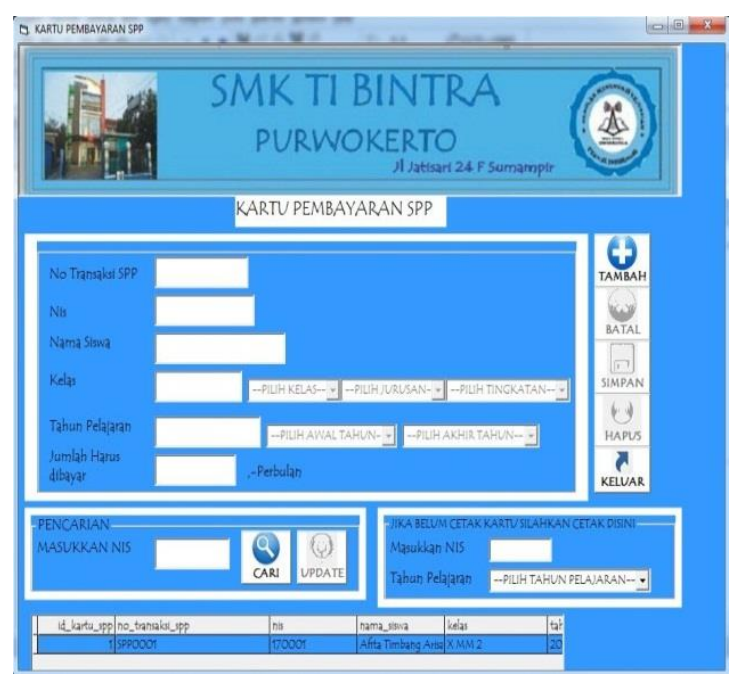

Gambar 10. Tampilan form kartu pembayaran SPP 


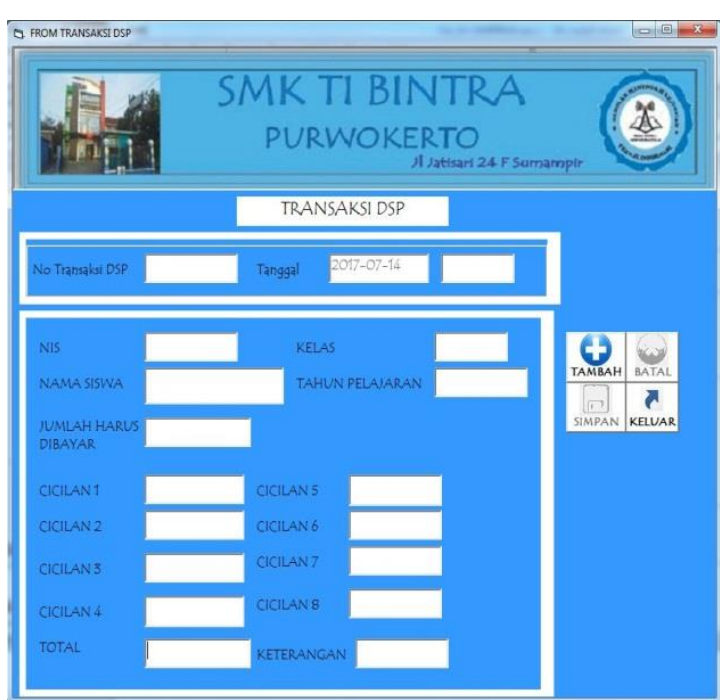

Gambar 11. Tampilan form transaksi DSP

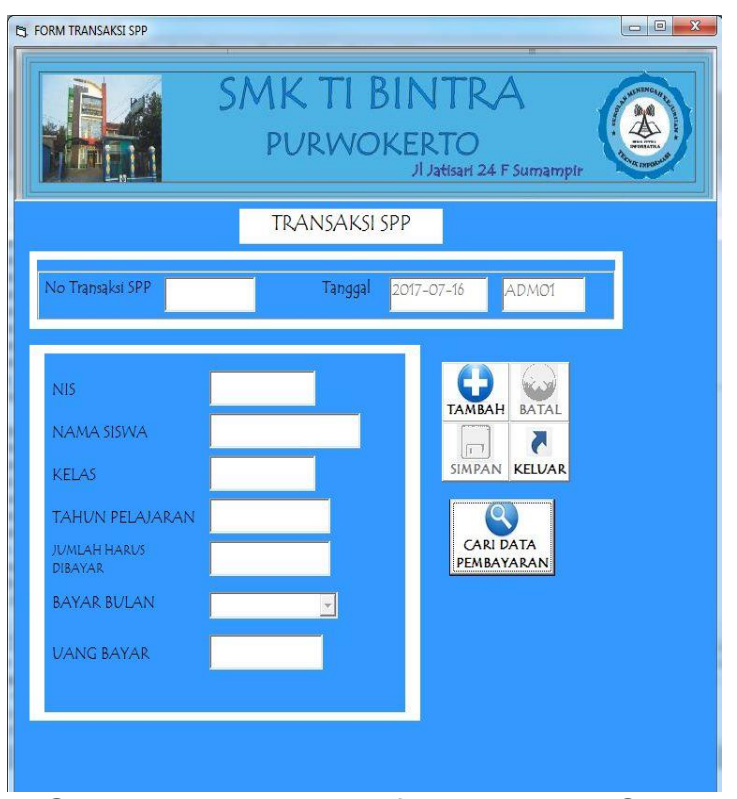

Gambar 12. Tampilan form transaksi SPP

Tampilan untuk print out atau laporan pembayaran DSP dan SPP berupa laporan pembayaran dsp dan laporan pembayaran spp.

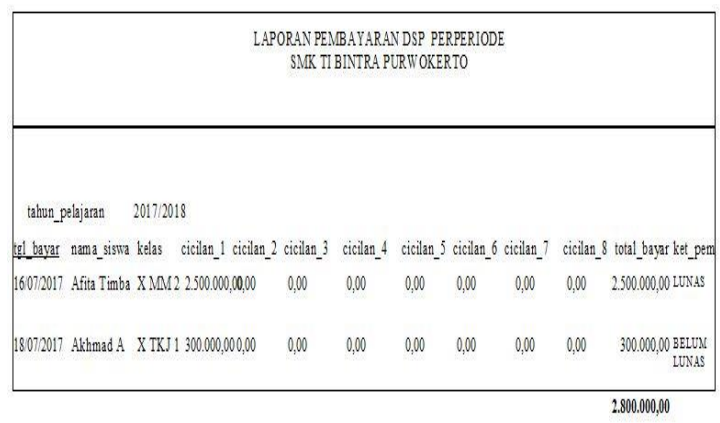

Gambar 13. Laporan pembayaran dsp

\begin{tabular}{|c|c|c|c|c|c|c|c|c|}
\hline \multicolumn{9}{|c|}{$\begin{array}{l}\text { LAPORAN PFNBAYARAR SPP } \\
\text { SMKK TIBMTRA } \\
\text { PURW OKERTO }\end{array}$} \\
\hline Tanzzal Bxyar & & Noo Transaks i SPP & $\underline{N 15}$ & Nama Sisas & $\underline{\text { Kelass }}$ & Tratur Pe peize & mBazar Buan & Iode Adimin $\mathrm{ke}$ \\
\hline \begin{tabular}{|l|l}
160720017 \\
\end{tabular} & 2 & SPP0002 & 170002 & LIII & XIMMI2 & $2017 / 2018$ & JULI & \\
\hline $1607 / 2017=$ & 2 & SPP0002 & 170002 & LILI & XIMMI2 & 20172018 & Agustus & 1 \\
\hline $160720017=$ & 2 & SPP0002 & 170002 & LIII & XIMM 2 & 20172018 & SEPTEMGE & 1 \\
\hline $160720017 \quad 2$ & 2 & SPP0002 & 170002 & LIII & XIMMn 2 & 20172018 & OKTOBER & 1 \\
\hline $16072017 \quad 2$ & 2 & SPP0002 & 170002 & LIII & XIMMa2 & 20172018 & NOVEMBBE & 1 \\
\hline $160772017 \quad 3$ & 3 & SPP0002 & 170002 & LIII & XIMM2 & 201720018 & $\pi L I$ & 2 \\
\hline $160772017 \quad 3$ & 3 & SPP0002 & 170002 & LIIII & xrMan 2 & 20172018 & Agustus & 2 \\
\hline $16072017 \quad 3$ & 3 & SPP0002 & 170002 & LIII & XIMMar & 20172018 & SEPIEMGE & 2 \\
\hline $1600720017 \quad$ & 3 & SPP0002 & 170002 & LIII & XIM⿻上2 & 201772018 & OKTOBER & 2 \\
\hline $16072017 \quad \exists$ & 3 & SPP0002 & 170002 & LIII & XIMM 2 & 20172018 & NoveMBE & ${ }^{2}$ \\
\hline 160772017 & 6 & SPP0002 & 170002 & LIII & XIMM:2 & 20172018 & suL & 3 \\
\hline 16072017 & 6 & SPP0002 & 170002 & LIII & XIMM 2 & $2017 / 2018$ & Agustus & 3 \\
\hline 160720017 & 6 & SPP0002 & 170002 & LIII & XIMMn2 & 20172018 & SEPTENBE & 3 \\
\hline 160772017 & 6 & SPP00002 & 170002 & LIII & XIMM 2 & 2017/2018 & OKTOBER & $3^{3}$ \\
\hline 10072017 & . & SPP0002 & 170002 & LIII & $\mathrm{xrMM} 2$ & 20172018 & Novembe & ${ }^{3}$ \\
\hline 160720178 & 8 & SPP0002 & 170002 & LIII & XIMMn 2 & 20172018 & $\pi L I$ & 4 \\
\hline 16072017 & 8 & SPP0002 & 170002 & LIII & XIMMn 2 & $2017 / 2018$ & Agustus & 4 \\
\hline 160772017 s $\mathrm{s}$ & 8 & SPP0002 & 170002 & LIIII & XIMMar & 20172018 & SEPTEMBE & \\
\hline 160772017 s & 8 & SPP0002 & 170002 & LIII & XIMM 2 & 201772018 & OKTOBER & \\
\hline 6072017 & & SPP0002 & 100 & LiIT & $\mathrm{aN}$ & 12018 & NOVEMBEE & \\
\hline
\end{tabular}

Gambar 14. Laporan pembayaran spp

Bentuk Logical Record Structure (LRS) pada aplikasi pembayaran DSP dan SPP sekolah yang dapat digambarkan seperti dibawah ini:

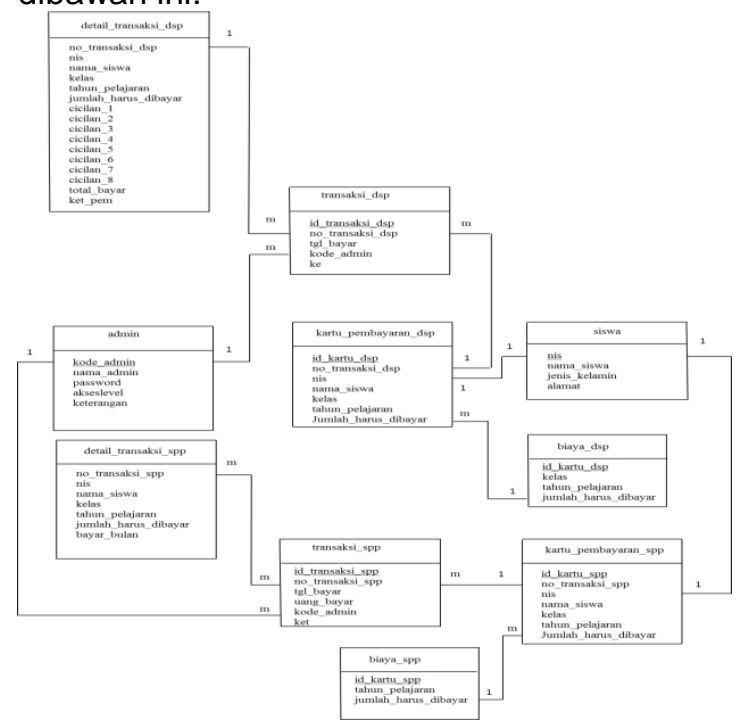

Gambar 15. Logical Record Structure (LRS)

Dalam aplikasi pembayaran DSP dan SPP ini terdapat beberapa menu yaitu login master, cetak kartu pembayaran, transaksi, laporan, tools dan keluar. Login digunakan oleh admin untuk masuk ke menu utama aplikasi DSP dan SPP. Menu master digunakan untuk mengolah data admin dan data siswa. Menu Cetak kartu pembayaran di gunakan untuk mencetak kartu pembayaran DSP dan SPP. Menu transaksi digunakan untuk mengolah data transaksi DSP dan SPP. Menu laporan digunakan untuk mencetak laporan pembayaran DSP dan SPP. Menu tools terdapat submenu ganti password digunkan untuk menganti password admin. Menu keluar digunakan untuk keluar dari aplikasi. Berikut ini adalah diagram HIPO 
untuk aplikasi pembayaran DSP dan SPP sekolah:

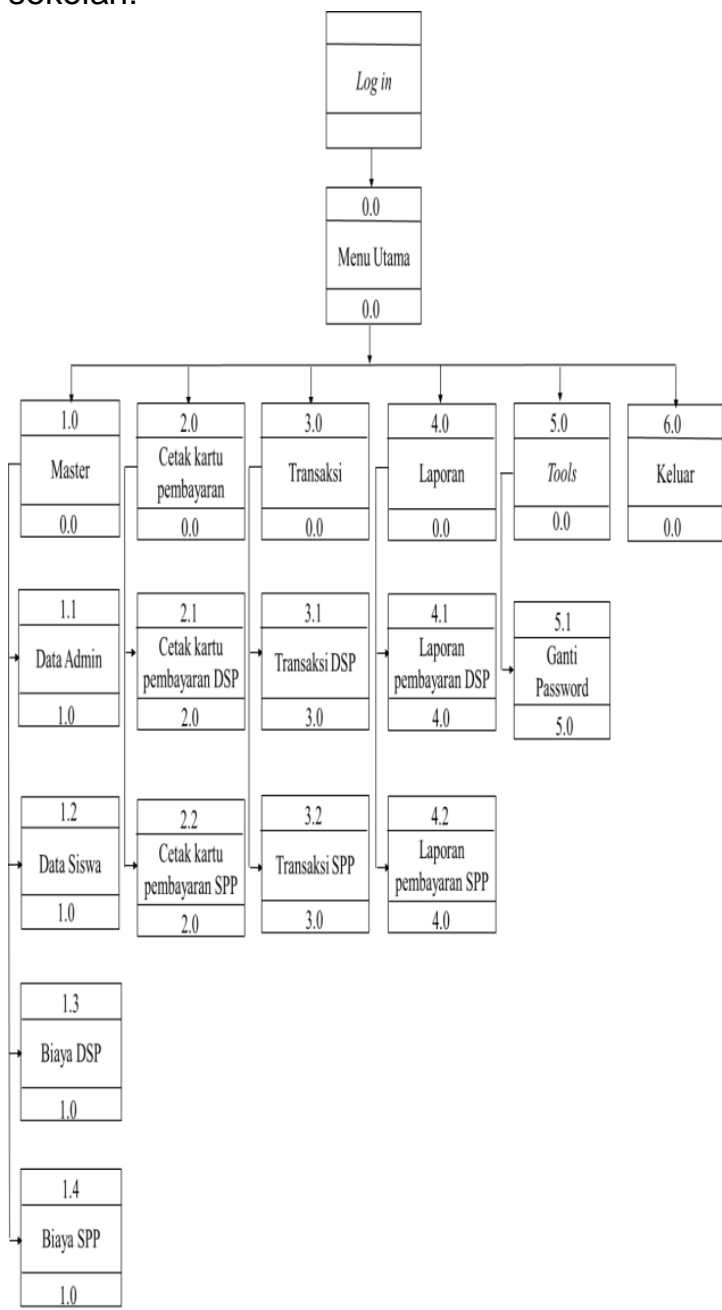

Gambar 16. Diagram Hierarchy Input Process Output (HIPO)

\section{E. KESIMPULAN DAN SARAN}

\section{Kesimpulan}

Berdasarkan pembahasan yang telah di bahas pada bab-bab sebelumnya, penulis mencoba menarik kesimpulan mengenai aplikasi DSP dan SPP pada SMK TI BINTRA Purwokerto dengan menggunakan Microsoft Visual Basic 6.0 sebagai berikut:

a) Dapat meningkatkan efektifitas dan efisiensi dalam proses pengolahan data pembayaran.

b) Data dapat disimpan dalam jumlah besar secara aman dan lebih terjamin dengan menggunakan password.

c) Dapat mengurangi kesalahan pencatatan akibat human error.

d) Memberi kemudahan dalam memasukan data, mengolah data, mencari data dan dalam mencetak data yang diperlukan.

\section{Saran}

Dari kesimpulan yang penulis berikan di atas, maka penulis memberikan suatu masukan yang berupa saran yang membangun demi terus berkembangnya Program DSP dan SPP pada SMK TI BINTRA Purwokerto, antara lain:

a) Pentingnya file cadangan (backup) untuk menghindari kehilangan data yang tersimpan di komputer karena berbagai faktor penyebab.

b) Perlu adanya pengetahuan dan pelatihan bagi user dalam menjalankan aplikasi DSP dan SPP.

c) Pada periode tertentu perlu adanya pengecekan kembali dan pembaharuan aplikasi yang diusulkan guna menjaga dan meningkatkan kualitas aplikasi tersebut.

d) Untuk menjaga data agar aman dari pemakai yang tidak bertanggung jawab maka password yang sudah dibuat hanya boleh diketahui oleh user atau admin.

\section{DAFTAR PUSTAKA}

[1] Fatta, Hanif Al. 2007. Analisis Perancangan Sistem Informasi untuk Keunggulan Bersaing Perusahaan dan Organisasi Modern. Yogyakarta: Andi.

[2] Fathansyah, Ir. 2007. Basis Data. Bandung: Informatika Bandung.

[3] Fayeldi, Trija., dan Syerif Nurhakim. 2012. Teknologi Modern Pemikiran Fenomenal Menuju Modernisasi ke Masa Depan. Jakarta: Bestari Kids.

[4] Junaedi, Fajar EP. 2007. Algoritma dan Pemrograman. Jakarta: Salemba Infotex.

[5] Kadir, Abdul. 2012. Algoritma \& Pemrograman menggunakan Java. Yogyakarta: Andi.

[6] Kartono, St. 2009. Sekolah Bukan Pasar. Jakarta: PT Kompas Media Nusantara.

[7] Kusrini dan Andri Koniyo. 2007. Tuntunan Praktis Membangun Sistem Informasi dengan Visual Basic dan Microsoft SQL Server. Yogyakarta: Andi.

[8] Lubis, Adyanata. 2016. Basis Data Dasar untuk mahasiswa ilmu komputer. Yogyakarta: CV Budi Utama.

[9] MADCOMS. 2008. Microsoft Visual Basic 6.0 untuk Pemula. Yogyakarta: Andi.

[10] MADCOMS. 2010. Mahir dalam 7 hari: Microsoft Visual Basic $6.0+$ Crystal Report 2008. Yogyakarta: Andi.

[11] Nugroho, Bunafit. 2009. PHP dan MySQL dengan Editor Dreamweaver MX. Yogyakarta: Andi. 
[12] Rahmat, Antonius. 2010. Algoritma dan Pemrograman dengan Bahasa CKonsep, teori, dan implementasi. Yogyakarta: Andi.

[13] Rosa A.S., dan M. Shalahuddin. 2014. Rekayasa Perangkat Lunak dan Berorientasi Objek. Bandung: Informatika Bandung.

[14] Simarmata, Janer., dan Iman Paryudi. 2010. Basis Data. Yogyakarta: Andi.

[15] Sitorus, Lamhot. 2015. Algoritma dan Pemrograman. Yogyakarta: Andi.

[16] Suarga. 2012. Algoritma dan Pemrograman. Yogyakarta: Andi.

[17] Tabrani, Muhamad. 2014. Implementasi Sistem Informasi Reservasi Penginapan Pada Argowisata Gunung Mas Cisarua Bogor. Jakarta: Bianglala Informatika Vol II No 1 Maret 2014.

[18] Wardana. 2016. Aplikasi Website Profesional dengan PHP dan jQuery. Jakarta: PT Elex Media Komputindo. 